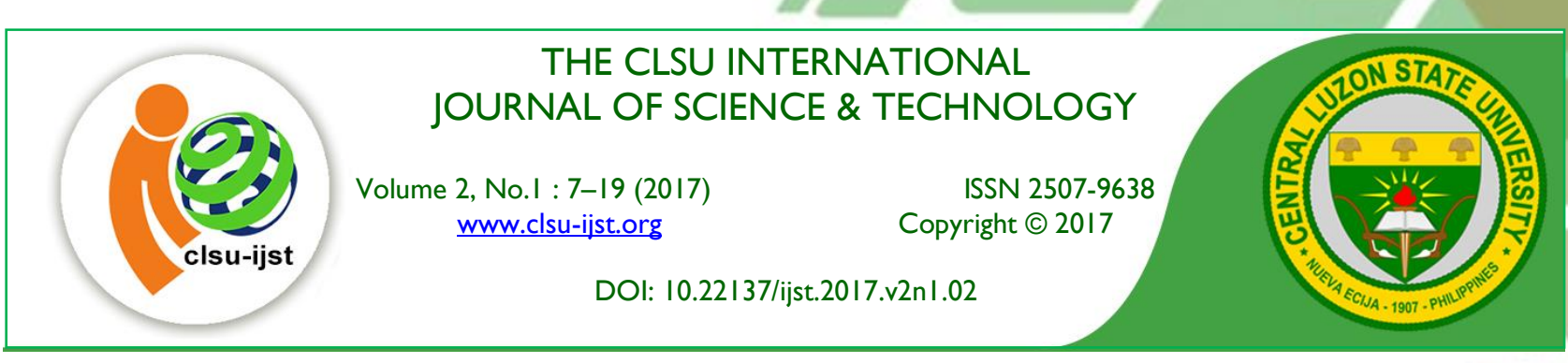

\title{
Alkali Pretreatment of Rice Straw to Enhance Enzymatic Hydrolysis for Bioethanol Production
}

\author{
Wendy C. Mateo ${ }^{1}$, Victorino T. Taylan ${ }^{1}$, Perla C. Florendo ${ }^{2}$, Rosalie R. \\ Rafael $^{3}$, and Emmanuel V. Sicat ${ }^{1}$
}

${ }^{1}$ Department of Agricultural and Biosystems Engineering, College of Engineering, Central Luzon State University, ${ }^{2}$ Philippine Carabao Center, and ${ }^{3}$ Department of Chemistry, College of Arts and Sciences, Central Luzon State University, Philippines

Email for correspondence: wcmateo@yahoo.com.ph

Submitted 23 March 2017, Accepted 26 March 2017, Published online 31 March 2017

\section{ABSTRACT}

The study was conducted to evaluate the effect of alkali pretreatment of rice straw on enzymatic hydrolysis for bioethanol production. The experiments conducted were divided into two studies. For Study 1, rice straw was treated with different concentrations $(0.5 \%, 1.0 \%$, and $1.5 \%)$ of sodium hydroxide $(\mathrm{NaOH})$ and steeping durations (15, 30, and 45 hours). Alkali pretreated rice straws were subjected to enzymatic hydrolysis using cellulase complex (NS22074). In the second study, untreated rice straw as well as rice straw treated with $\mathrm{NaOH}$ (conditions as determined in the first study), were subjected to enzymatic hydrolysis using three different enzyme combinations of cellulase complex (NS22074), xylanase (NS22036), and hemicellulase (NS22002), and yeast fermentation using Saccharomyces cerevisae.

Results of Study 1 revealed that $\mathrm{NaOH}$ concentrations and steeping durations significantly affect the enzymatic hydrolysis of rice straw to fermentable sugars. Rice straws treated with $1.5 \%$ $\mathrm{NaOH}$ solution steeped for 45 hours had the highest reducing sugar of $0.5402 \mathrm{~g}$ and conversion efficiency at $56.85 \%$. Thus, these conditions were used in Study 2. In this study, it was found that pretreatment and different enzyme combinations have a highly significant effect on enzymatic conversion of rice straw to fermentable sugars. Alkali pretreated rice straw hydrolyzed using three enzyme combinations - cellulose complex, xylanase, and hemicellulase-obtained the highest reducing sugar of $0.7396 \mathrm{~g}$ and conversion efficiency at $77.88 \%$.

Alkali pretreatment, specifically sodium hydroxide $(\mathrm{NaOH})$ at $1.5 \%$ concentration, and steeping for 45 hours of rice straw was an effective pretreatment to enhance enzymatic hydrolysis in terms of increase in reducing sugar and conversion efficiency. Similarly, alkali pretreatment of rice straw had significant advantage over untreated rice straw in enhancing the effect of enzymes cellulase complex, xylanase, and hemicellulase in enzymatic hydrolysis. After yeast fermentation using Saccharomyces cerevisiae, ethanol yield of the study ranged from $0.0354 \mathrm{~g}$ to $0.0781 \mathrm{~g} / \mathrm{g}$ glucose, or 41.18 to $51.51 \%$ of the maximum theoretical yield.

Key words : bioethanol, ensymatic hydrolysis, pretreatment, rice straw, yeast fermentation 
The Philippine Biofuels Act of 2006 mandates that all liquid fuels for motors and engines sold in the country must contain at least $5 \%$ ethanol by February 2009, and by 2011 , the mandated blend can go up to $10 \%$. However, the Philippines is importing bio-ethanol to meet the mandated bio-ethanol blend of 10\% (Corpuz 2010). Currently, there are only three ethanol production facilities operating (2 sugarcane and 1 molasses-based) with a combined annual production capacity of about 69 million liters which is not enough to supply the 271.22 million liter ethanol demand of the country. Ethanol production from sugarcane molasses and starch from corn is already being done. However, production of fuel ethanol from such feedstock can invite shortage of food resources.

Bioethanol production from lignocellulosic biomass can avoid competition with food production, offer considerable potential to promote rural development, and increase the overall economic situation in emerging and developing countries. Lignocellulosic biomass includes agricultural residues, forestry residues, wood products, yard wastes, and municipal solid wastes.

Rice is one of the Philippine major crops producing a large amount of rice straw as solid biomass waste seasonally. Rice straw, a lignocellulosic biomass, is an attractive alternative feedstock for ethanol production because it is readily available, abundant, renewable, and considered to be carbon neutral. Jiang, as cited by Kargbo et al. (2007), stated that straw as agricultural waste biomass can be a source of alternative energy to substitute fossil energy for reducing greenhouse gas emission as well as avoid local pollution problems from open burning. It can be converted into sugars via enzymatic hydrolysis and continuously fermented into bioethanol by fermentation process using yeast.

Rice straw is one of the most abundant lignocellulosic waste materials and byproduct of riceproducing countries like the Philippines. It is usually subjected to open-field burning causing haze and other environmental problems. It is estimated that 11.5 million tons of total rice straw can be produced in the Philippines annually. This amount can potentially produce 1.451 billion liters ethanol considering production from total rice straw and 290 million liters ethanol considering production from rice straw availability (Yano et al. 2008).

Lignocellulosic materials have complex structural configuration that needs to be broken down to make cellulose more accessible to the enzymes that convert carbohydrate polymers into fermentable sugars. Hence, pretreatment of rice straw to enhance enzymatic hydrolysis for bioethanol production was considered in this study.

The general objective of the study was to subject rice straw to alkali pretreatment process in order to enhance enzymatic hydrolysis for bioethanol production. Specifically, the study aimed to:

1. determine the effect of different sodium hydroxide concentrations and steeping durations on the enzymatic conversion of rice straw to fermentable sugars;

2. determine the effect of pretreatment and different enzyme combinations on the enzymatic conversion of rice straw to fermentable sugar and;

3. determine the yield of ethanol from yeast fermentation of hydrolyzed rice straw. 


\section{MATERIALS AND METHODS}

Alkali pretreatment of rice straws to enhance enzymatic hydrolysis for bioethanol production was divided into two studies. Study 1 involved the biomass preparation, pretreatment of rice straws using different alkali concentrations and steeping durations, and enzymatic hydrolysis of alkali treated rice straws. Study 2 involved pretreatment of rice straws, enzymatic hydrolysis with three (3) different enzyme combinations, and yeast fermentation of enzyme hydrolysates.

\section{Study I. Alkali Pretreatment and Subsequent Enzymatic Hydrolysis of Rice Straws}

The first study was done to determine the optimal concentration of sodium hydroxide $(\mathrm{NaOH})$ and steeping duration for alkali pretreatment which enhanced enzymatic hydrolysis of rice straws in terms of reducing sugars and conversion efficiency. The selected pretreatment conditions were used in the second study.

Biomass preparations. Rice straws including stubbles were collected after threshing from rice fields in Brgy. Licaong, Science City of Muñoz, Nueva Ecija, Philippines. The biomass was collected while it was fresh to avoid maillard reaction of carbohydrates with protein due to thermal degradation resulting to indigestible components and irreversible reaction. Cleaned rice straws were not washed with water to avoid partial hydrolysis and absorption of moisture that will affect the total solids of original biomass. The cleaned straws were chopped to approximately 10 centimeters in length, placed in plastic bags, and stored at $-20^{\circ} \mathrm{C}$ until needed. Prior to pretreatment, rice straws were cut to approximately $2 \mathrm{~cm}$ and ground by screw type grinders used for grinding glutinous rice available in the market. Ground rice straws were placed in plastic bags and stored in a freezer at $-20^{\circ} \mathrm{C}$ until needed.

Analysis of Rice Straw Composition. Before the pretreatment process, total solids, reducing sugars, and holocellulose content of rice straws were analyzed following the Laboratory Analytical Procedure (LAPs) released by the National Renewable Energy Laboratory (NREL) (Sluiter et al. 2005). All laboratory analyses were done at the Nutrition Laboratory of the Philippine Carabao Center (PCC) at Central Luzon State University (CLSU).

Alkali Pretreatment of Rice Straw. Ground rice straws were pretreated using different concentrations of $\mathrm{NaOH}$ solution i.e., $0.5 \%, 1.0 \%$, and $1.5 \%$ concentrations and different steeping durations of 15,30 , and 45 hours in a water bath at $55^{\circ} \mathrm{C}$. A ratio of $1: 5(\mathrm{w} / \mathrm{v})$ rice straw and $\mathrm{NaOH}$ solution was used. Twenty (20) grams of ground rice straws were used per treatment with three replications. Each replicate was added with $100 \mathrm{~mL}$ of $\mathrm{NaOH}$ solution. Samples were steeped in a temperature controlled water bath at $55^{\circ} \mathrm{C}$ according to the treatment parameter. After steeping, the hydrolysates were pressed through cheese cloth. Alkali treated rice straws were washed with hot purified water until the $\mathrm{pH}$ reached 7.0-7.05. All washed alkali pretreated rice straws were stored in a freezer at $-20^{\circ} \mathrm{C}$ prior to enzymatic hydrolysis.

Enzymatic Hydrolysis of Alkali Pretreated Rice Straw. Cellulase complex (NS22074, Novozyme) was used in the enzymatic hydrolysis of alkali pretreated rice straws. This enzyme catalyzed the breakdown of cellulosic material into glucose, cellobiose, and higher glucose polymers. The cellulase complex with an activity of 1000 EGU (endoglucanase unit)/g was added at $5 \%(w / w)$ of the total solid of sample.

Enzymatic Hydrolysis Procedure. Ten grams of alkali treated rice straws were loaded in $125 \mathrm{~mL}$ sterilized serum bottle. Three replications were made for each treatment. Each sample was added with citrate buffer $(\mathrm{pH} 4.8,50 \mathrm{mM})$ at 1:20 ratio of sample and buffer solution, $40 \mu \mathrm{g} / \mathrm{mL}$ of antibiotic tetracycline, $40 \mu \mathrm{g} / \mathrm{mL}$ ketoconazole, and sterilized water to fill up volume to $100 \mathrm{~mL}$. Palmtop $\mathrm{pH}$ meter was used to measure the initial $\mathrm{pH}$. The $\mathrm{pH}$ was adjusted to $\mathrm{pH} 5$ by the addition of sodium Vol. 2 No. 1 (March 2017) | ISSN: 2507-9638 | DOI: 10.22137/ijst.2017.v2n1.02 
hydroxide solution. The enzymes were aseptically added to the bottles. All serum bottles were sealed with rubber butyl cap and crimped with aluminum seal. The sealed bottles were incubated in a water bath at $50^{\circ} \mathrm{C}$ shaking at $150 \mathrm{rpm}$ for 72 hours. After reaction time, the enzyme hydrolyzates were placed in the chiller $\left(4^{\circ} \mathrm{C}\right)$ until analyzed. Ten (10) milliliter of the supernatant was obtained and analyzed for reducing sugars. The remaining enzyme hydrolysates were stored in the chiller at $4^{\circ} \mathrm{C}$ for backup analysis. The alkali pretreatment condition which gave the highest reducing sugar and conversion efficiency on enzymatic hydrolysis was used in the second study.

\section{Study 2. Process of Bioethanol Production from Rice Straws}

Alkali pretreatment conditions predetermined as $1.5 \% \mathrm{NaOH}$ and steeping of 45 hours were done. Three enzyme combinations were used in the enzymatic hydrolysis. The effect of pretreatments was evaluated in the subsequent enzymatic hydrolysis using enzyme combinations and fermentation in ethanol by Saccharomyces cerevisiae.

Pretreatment. Untreated and alkali treated rice straws were used. Untreated rice straws were used as control. For alkali-treated rice straws, $50 \mathrm{~g}$ of ground rice straws were pretreated with $250 \mathrm{~mL}$ of $1.5 \% \mathrm{NaOH}$ solution and steeped for 45 hours in a temperature controlled water bath at $55^{\circ} \mathrm{C}$. A ratio of $1: 5(\mathrm{w} / \mathrm{v})$ rice straw and $\mathrm{NaOH}$ solution was also used. After steeping, the alkali-treated rice straws were pressed through cheesecloth and washed with hot purified water until it attained $\mathrm{pH} 7.0$ 7.05. All washed pretreated rice straws were stored in a freezer at $-20^{\circ} \mathrm{C}$ for further use.

Enzymatic Hydrolysis. Three enzymes, cellulose complex (NS22074, Novozyme), xylanase (NS22036, Novozyme), and hemicellulase (NS22002, Novozyme), were used for the enzymatic hydrolysis of untreated and alkali pretreated rice straws. Cellulase complex is a specific enzyme that catalyze the breakdown of cellulose into glucose. Xylanase is a specific enzyme for efficiently degrading linear-branched xylan into xylose. Hemicellulase, on the other hand, is a specific enzyme for solubilization of hemicelluloses into 5-carbon sugars such as arabinose and mannose. Cellulase complex with an activity of $1000 \mathrm{EGU} / \mathrm{g}$ biomass was added at 5\%(w/w) total solid of samples. Xylanase with an activity of 1000 FXU-S (Fungal Xylanase unit) $/ \mathrm{g}$ biomass was added at $0.25 \%$ (w/w) total solid of samples. Hemicellulase with an activity of 45 FBG (Fungal $\beta$-Glucanase Unit)/g biomass was added at $2 \%(\mathrm{w} / \mathrm{w})$ total solid of samples. All three enzymes were added based on their maximum recommended dosage as indicated in Table 3. These resulted in a ratio combination of 20:1:8 of cellulose complex:xylanase:hemicellulase. Ten (10) grams of untreated and alkali-treated rice straws were loaded in $125 \mathrm{~mL}$ sterilized serum bottle. Three replications were made for each treatment. Each sample was added with citrate buffer $(\mathrm{pH} 4.8,50 \mathrm{mM})$ at 1:20 ratio of sample and buffer solution, 40 $\mu \mathrm{g} / \mathrm{mL}$ of antibiotic tetracycline, $40 \mu \mathrm{g} / \mathrm{mL}$ ketoconazole, and sterilized water to fill up volume to 100 $\mathrm{mL}$. Sodium hydroxide solution was used to adjust the initial $\mathrm{pH}$ to 5. Palmtop $\mathrm{pH}$ meter with probe was used in measuring $\mathrm{pH}$. The enzymes were aseptically added to the bottles. All serum bottles were sealed with rubber butyl cap and crimped with aluminum seal. Sealed bottles were incubated in a water bath at $55^{\circ} \mathrm{C}$ shaking at $150 \mathrm{rpm}$ for 72 hours. Upon completion, serum vials were placed in the chiller. Ten (10) milliliter of the supernatant was analyzed for reducing sugars. Remaining samples were stored in the chiller for backup analysis and yeast fermentation.

Fermentation of Hydrolyzates. Enzyme hydrolyzates were centrifuged for 10 minutes at 12,000 $\mathrm{rpm}$. The supernatant were transferred into sterilized serum bottles. The $\mathrm{pH}$ of the hydrolysates was normalized to 7.0 using $2.67 \mathrm{M}$ sodium hydroxide solution. After $\mathrm{pH}$ was adjusted, $50 \mathrm{~mL}$ of hydrolysates per sample was transferred to $125 \mathrm{~mL}$ sterilized serum bottles. The serum bottles were sealed with rubber butyl cap and crimped with aluminum seal prior to sterilization. Sterilization was done to inactivate enzymes, antibiotic, and any contaminating microorganisms prior to yeast fermentation. The fermentation bottles were aseptically inoculated with freshly propagated culture of Saccharomyces cerevisiae. The bottles were incubated for anaerobic fermentation for 72 hours in a temperature-controlled water bath at $32^{\circ} \mathrm{C} \pm 2^{\circ} \mathrm{C}$. After fermentation, $10 \mathrm{~mL}$ of liquid samples was used Vol. 2 No. 1 (March 2017) ISSN: 2507-9638 | DOI: 10.22137/ijst.2017.v2n1.02 
for the 3, 5-dinitrosalicylic acid analysis for reducing sugars. Theoretical yield of ethanol was determined based on the utilized glucose after fermentation process.

\section{Parameters Analyzed}

Reducing sugar. Percentage of reducing sugar in rice straw was analyzed by dinitrosalycilic acid (DNS) assay with glucose as standard and calculated using the formula:

$$
\mathrm{RS}=\frac{\mathrm{G} \times \mathrm{V} \times \mathrm{df}}{\mathrm{Ws} \times \% \mathrm{TS}} \times 100 \%
$$

Where:

RS = fermentable sugars released from cellulose and hemicelluloses after enzymatic hydrolysis (\%)

$\mathrm{G}=$ the amount of glucose determined from the linear equation on the standard curve where concentration is represented as $\mathrm{Y}=$ slope of the equation multiplied by absorbance (X factor). (g/L)

$\mathrm{V}=$ total volume of hydrolysates $(\mathrm{L})$

$\mathrm{df}=$ dilution factor

Ws = sample weight $(\mathrm{g})$

$\% \mathrm{TS}=$ percent total solids of the biomass

Enzyme hydrolysates and yeast hydrolysates reducing sugar were analyzed by means of dinitrosalycilic acid (DNS) assay with glucose as standard and calculated using the formula:

$$
\mathrm{RS}=\mathrm{G} \times \mathrm{V} \times \mathrm{df}
$$

Where:

RS = fermentable sugars released from cellulose and hemicelluloses after enzymatic hydrolysis ( $\mathrm{g}$ )

$\mathrm{G}=$ the amount of glucose determined from the linear equation on the standard curve where concentration is represented as $\mathrm{Y}=$ slope of the equation multiplied by absorbance $(\mathrm{X}$ factor). $(\mathrm{g} / \mathrm{L})$

$\mathrm{V}=$ total volume of hydrolysates $(\mathrm{L})$

$\mathrm{df}=$ dilution factor

Conversion Efficiency. The conversion efficiency of enzymatic hydrolysis was calculated using the following formula (NREL 2010).

$$
\mathrm{CE}=\mathrm{RS} \text { G } \times 100 \%
$$

Where:

$\mathrm{CE}=$ conversion efficiency $(\%)$

$\mathrm{RS}=$ amount of hydrolyzed glucose $(\mathrm{g})$

$\mathrm{G}=$ maximum amount glucose found in samples (g)

Ethanol yield. Ethanol yield was calculated using the following formula:

$$
\mathrm{E}=\frac{\mathrm{G} \times 2 \mathrm{mols} \text { ethanol } \times \mathrm{MWe}}{\mathrm{MWg}}
$$

Where:

$\mathrm{E}=$ calculated ethanol yield based on utilized glucose after fermentation $(\mathrm{g})$

$\mathrm{G}=$ gram glucose produce at maximum hydrolysis (g)

MWe $=$ molecular weight of ethanol $(46 \mathrm{~g} / \mathrm{mol})$

$\mathrm{MWg}=$ molecular weight of glucose $(180 / \mathrm{mol})$ 


\section{$\underline{\text { CLSU International Journal of Science \& Technology, Mateo }}$ \\ $\operatorname{Ymax}(\%)=\mathrm{E} G \times 0.511 \times 100 \%$ \\ Ymax $=$ percentage of theoretical maximum ethanol yield $(\%)$ \\ $\mathrm{E}=$ ethanol produced during fermentation $(\mathrm{g})$ \\ $0.511=$ theoretical yield of ethanol produced from glucose by Saccharomyces cerevisiae}

Where:

$\mathrm{G}=$ glucose in the hydrolysates $(\mathrm{g})$

\section{Statistical Design and Analysis}

Study 1. Alkali Pretreatment and Subsequent Enzymatic Hydrolysis. Three (3) sodium hydroxide $(\mathrm{NaOH})$ concentrations and 3 steeping durations were used for the determination of $\mathrm{NaOH}$ concentration and steeping duration for alkali pretreatment of rice straws. Each treatment combination was replicated three times.

$\mathrm{C}-\mathrm{NaOH}$ Concentration (Factor $\mathrm{A})$

$\mathrm{C} 1-0.5 \%$

$\mathrm{C} 2-1.0 \%$

C3 $-1.5 \%$

D - Steeping duration (Factor B)

D1 - 15 hours

D2 - 30 hours

D3 - 45 hours

Relevant data were gathered and recorded, organized, tabulated, and analyzed statistically using 3 x 3 factorial in Randomized Complete Block Design (RCBD). Comparisons among treatment means were done using Duncan's Multiple Range Test (DMRT).

Study 2. Process of Bioethanol Production from Rice Straw. Two (2) factors were used in this study. Each treatment combination was replicated three times.

Factor A - Pretreatment

A1 - Untreated rice straw (Control)

A2 -Alkaline treated rice straw $(\mathrm{NaOH}$ concentration and steeping duration were taken from optimization study)

Factor B - Enzyme Combination

B1 - Single enzyme (Cellulase complex)

B2 - Combination of two enzymes (Cellulase complex and Xylanase)

B3 - Combination of three enzymes (Cellulase complex, Xylanase and Hemicellulase)

Data were collected and analyzed statistically using 2 × 3 factorial in Completely Randomized Design (CRD) and Duncan's Multiple Range Test (DMRT) for the comparison among treatment means. 


\section{RESULTS AND DISCUSSION}

\section{Study I. Alkali Pretreatment and Subsequent Enzymatic Hydrolysis}

Rice Straw Composition. Total solid of the rice straw used in this study was $33.40 \%$. Reducing sugars and holocellulose content of the rice straw were $71.42 \%$ and $61.59 \%$, respectively. Holocellulose represents the cellulose and hemicellulose content of biomass (Chen et al. 2007).

Effect of Alkali Pretreatment on Total Solids of Rice Straws. Table 1 presents the mean total solids of alkali pretreated rice straws. The highest total solids was noted on the rice straw treated with $0.5 \% \mathrm{NaOH}$ and steeped for 15 hours at $18.53 \%$, while the lowest was treated with $1.5 \% \mathrm{NaOH}$ steeped for 45 hours at $13.29 \%$. It was also recorded that increased concentration of $\mathrm{NaOH}$ and longer steeping duration resulted to lower concentration of total solids in treated rice straws. Analysis of variance showed highly significant differences in the total solid content of pretreated rice straws using different concentrations of $\mathrm{NaOH}$ and steeping duration at $1 \%$ level of significance. However, interaction effect on total solids produced by both factors, i.e. $\mathrm{NaOH}$ concentration and steeping duration, was found not significant. This means that using higher concentration of $\mathrm{NaOH}$ in the pretreatment and steeped for a longer duration results to reduced amount of total solids or more dissolution of the solids in the rice straw.

Table 1. Total solids (\%) of alkali pretreated rice straws.

\begin{tabular}{ccccc}
\hline \multirow{2}{*}{ NAOH concentration } & \multicolumn{3}{c}{ Steeping duration } & \multirow{2}{*}{ Mean } \\
\cline { 2 - 4 } & $15 \mathrm{hrs}$ & $30 \mathrm{hrs}$ & $45 \mathrm{hrs}$ & \\
\hline $0.5 \%$ & 18.53 & 17.56 & 15.80 & $17.30^{\mathrm{a}}$ \\
$1.0 \%$ & 17.43 & 16.76 & 14.81 & $16.33^{\mathrm{ab}}$ \\
$1.5 \%$ & 16.72 & 15.67 & 13.29 & $15.23^{\mathrm{b}}$ \\
Mean & $17.56^{\mathrm{i}}$ & $16.66^{\mathrm{i}}$ & $14.63^{\mathrm{j}}$ & \\
\hline
\end{tabular}

Means with the same letters in rows and in columns are not significantly different at $5 \%$ level of significance by DMRT

Comparison among means on total solids of the alkali pretreated rice straw revealed $0.5 \%$ $\mathrm{NaOH}(17.30 \%)$ and $1.0 \% \mathrm{NaOH}(16.33 \%)$ treatments are not significantly different from each other; $1.0 \% \mathrm{NaOH}$ and $1.5 \% \mathrm{NaOH}(15.23 \%)$ are not significantly different from each other; while $0.5 \%$ and $1.5 \% \mathrm{NaOH}$ concentrations are significantly different from each other.

Comparison among means on total solids of alkali pretreated rice straws showed 15-hour $(17.56 \%)$ and 30 -hour $(16.66 \%)$ durations of steeping are not significantly different from each other but significantly different from 45-hour (14.63\%) steeping.

Results imply that increasing concentration of $\mathrm{NaOH}$ leads to more dissolution of solids in the pretreatment process. The higher the concentration of $\mathrm{NaOH}$ used, the lower the total solids. Similarly, the longer the steeping duration, the lower the total solids of pretreated rice straw. This reduction of total solids shows effective penetration of alkali on the lignocellulosic matrix of rice straw specifically holocellulose which is $61.59 \%$ of total solids. Pretreatment with $\mathrm{NaOH}$ degraded significantly lignin, cellulose and hemicelluloses and changed the physical structure of the lignocellulosic matrix of corn straw (Zhong et al. 2011). 
Reducing Sugar of Cellulase Hydrolyzed Pretreated Rice Straw. Reducing sugars are fermentable sugars released from cellulose and hemicellulose after enzymatic hydrolysis. Table 2 shows the amount of reducing sugar produced through enzymatic hydrolysis of the alkali pretreated rice straw using different concentrations of $\mathrm{NaOH}$ and steeping durations. The highest reducing sugar was recorded at $0.5402 \mathrm{~g}$ in the rice straw that was pretreated with $1.5 \% \mathrm{NaOH}$ and steeped for 45 hours. The lowest was $0.3935 \mathrm{~g}$ in $0.5 \% \mathrm{NaOH}$ and 15 hours treatment. The pretreatment with alkali resulted to exposure of the cellulose which was acted upon by the hydrolytic enzyme, cellulase complex, leading to the release of reducing sugars.

Table 2. Amount of reducing sugar (g) produced on cellulytic hydrolysis of the alkali pretreated rice straws using different $\mathrm{NaOH}$ concentrations and steeping durations.

\begin{tabular}{ccccc}
\hline \multirow{2}{*}{ NAOH concentration } & \multicolumn{3}{c}{ Steeping duration } & \multirow{2}{*}{ Mean } \\
\cline { 2 - 4 } & $15 \mathrm{hrs}$ & $30 \mathrm{hrs}$ & $45 \mathrm{hrs}$ & \\
\hline $0.5 \%$ & 0.3935 & 0.4296 & 0.4460 & $0.4231^{\mathrm{c}}$ \\
$1.0 \%$ & 0.4615 & 0.4817 & 0.5037 & $0.4823^{\mathrm{b}}$ \\
$1.5 \%$ & 0.5135 & 0.5258 & 0.5402 & $0.5265^{\mathrm{a}}$ \\
Mean & $0.4562^{\mathrm{k}}$ & $0.4790^{\mathrm{i}}$ & $0.4966^{\mathrm{i}}$ & \\
\hline
\end{tabular}

Means with the same letters in rows and in columns are not significantly different at $5 \%$ level of significance by DMRT

Analysis of variance shows highly significant differences in the reducing sugar content of the rice straws treated with different concentrations of $\mathrm{NaOH}$ and steeping durations. However, there was no significant difference noted between the interactions of the two factors.

Comparison among means revealed that the amount of reducing sugars produced on hydrolysis by the enzyme on the alkali pretreated rice straws was significantly different from each other. The highest concentration of $\mathrm{NaOH}$ used which was $1.5 \%$ and longest steeping duration of 45 hours produced the highest amount of reducing sugars at $0.5265 \mathrm{~g}$ after treatment with the hydrolytic enzyme. The lowest reducing sugar produced was in the rice straw treated with $0.5 \% \mathrm{NaOH}$ concentration at $0.4231 \mathrm{~g}$.

On the other hand, steeping duration significantly influenced the amount of reducing sugars produced on enzymatic hydrolysis of the alkali pretreated rice straw. Results revealed that the highest reducing sugar was $0.4966 \mathrm{~g}$ at 45 hours steeping, followed by $0.4790 \mathrm{~g}$ at 30 hours steeping, and the lowest was $0.4562 \mathrm{~g}$ at 15 hours steeping.

Results showed that the amount of reducing sugar produced on enzymatic hydrolysis is directly proportional to the concentration of $\mathrm{NaOH}$ solution and steeping duration used. The combination of higher concentration of $\mathrm{NaOH}$ and longer duration of steeping rice straw as pretreatment process led to increased reducing sugar produced on enzymatic hydrolysis. Glucan and xylan content of alkali pretreated samples was reduced with increased alkali concentration from 0.5 to $2.0 \%$ (Chen et al. 2007) The alkali pretreatment breakdown of xylan, in conjunction with substantial lignin reduction, significantly improved enzymatic hydrolysis. Similarly, prolonging steeping durations exposed the cellulose and other polysaccharides to hydrolysis by the enzyme resulting in the release of the reducing sugars.

Conversion Efficiency of Cellulase Complex on Pretreated Rice Straw. Conversion efficiency is the percentage of the ratio of the amount of hydrolyzed carbohydrates measured as reducing sugar after enzymatic hydrolysis and the amount of carbohydrates of biomass. Table 3 shows the conversion efficiency of the enzymatically hydrolyzed alkali pretreated rice straw using different $\mathrm{NaOH}$ concentrations and steeping durations. Results showed that the highest conversion efficiency of

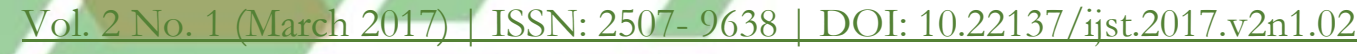


$56.85 \%$ was observed on $1.5 \% \mathrm{NaOH}$ concentration at 45 hours of steeping and the lowest, $29.65 \%$, was obtained using $0.5 \% \mathrm{NaOH}$ at 15 hours of steeping. Increasing $\mathrm{NaOH}$ concentration and steeping duration indicates higher conversion efficiency.

Table 3. Conversion efficiency ( $\%)$ of cellulase complex enzyme on rice straw pretreated with different $\mathrm{NaOH}$ concentrations and steeping durations.

\begin{tabular}{ccccc}
\hline \multirow{2}{*}{ NAOH concentration } & \multicolumn{3}{c}{ Steeping duration } & \multirow{2}{*}{ Mean } \\
\cline { 2 - 4 } & $15 \mathrm{hrs}$ & $30 \mathrm{hrs}$ & $45 \mathrm{hrs}$ & \\
\hline $0.5 \%$ & $29.65^{\mathrm{z}}$ & $34.17^{\mathrm{y}}$ & $39.42^{\mathrm{w}}$ & $34.41^{\mathrm{c}}$ \\
$1.0 \%$ & $37.00^{\mathrm{x}}$ & $40.11^{\mathrm{w}}$ & $47.47^{\mathrm{u}}$ & $41.53^{\mathrm{b}}$ \\
$1.5 \%$ & $42.90^{\mathrm{v}}$ & $46.84^{\mathrm{u}}$ & $56.85^{\mathrm{t}}$ & $48.86^{\mathrm{a}}$ \\
Mean & $36.52^{\mathrm{k}}$ & $40.37^{\mathrm{j}}$ & $47.92^{\mathrm{i}}$ & \\
\hline
\end{tabular}

Means with the same letters in rows and in columns are not significantly different at $5 \%$ level of significance by DMRT

Analysis of variance shows that $\mathrm{NaOH}$ concentrations and steeping durations have a highly significant effect on the conversion efficiency of the biomass to reducing sugars after enzymatic hydrolysis of the pretreated rice straw. Interaction of the two factors showed significant differences at $5 \%$ level of confidence.

Comparison among means of the conversion efficiency of alkali pretreated rice straws after enzymatic hydrolysis revealed significant differences using different $\mathrm{NaOH}$ concentrations of $0.5 \%$, $1.0 \%$, and $1.5 \%$. Highest conversion efficiency was $48.86 \%$ using $1.5 \% \mathrm{NaOH}$, followed by $41.53 \%$ using $1.0 \% \mathrm{NaOH}$, and the lowest was $34.41 \%$ using $0.5 \% \mathrm{NaOH}$ concentration.

In terms of steeping duration, comparison among means of the conversion efficiency after enzymatic hydrolysis of alkali pretreated rice straws showed that significant difference between 15, 30, and 45 hours of steeping. Highest conversion efficiency recorded was $47.92 \%$ in the rice straws steeped for 45 hours, followed by $40.37 \%$ at 30 hours, and the lowest was $36.52 \%$ at 15 hours.

Analysis of variance showed that there was significant interaction effect of the $\mathrm{NaOH}$ concentration used and steeping duration on the conversion efficiency after enzymatic hydrolysis of the alkali pretreated rice straw. Conversion efficiency was highest at $1.5 \% \mathrm{NaOH}$ steeped for 45 hours at $56.85 \%$, followed by the same concentration of $\mathrm{NaOH}(1.5 \%)$ steeped for 30 hours at $46.84 \%$, and $1.0 \% \mathrm{NaOH}$ steeped for 45 hours (47.47\%). This was followed by $1.5 \% \mathrm{NaOH}$ steeped for 15 hours (42.90\%), followed by $1.0 \%$ steeped for 30 hours $(40.11 \%)$, and $0.5 \% \mathrm{NaOH}$ steeped for 45 hours $(39.42 \%)$, followed by $1.0 \% \mathrm{NaOH}$ steeped for 15 hours $(37.00 \%)$, followed by $0.5 \% \mathrm{NaOH}$ steeped for 30 hours $(34.17 \%$ ). Lowest conversion efficiency after enzymatic hydrolysis was recorded at $0.5 \%$ $\mathrm{NaOH}$ with 15 hours of steeping (29.65\%).

Statistical analysis revealed the conversion efficiency of pretreated rice straw is directly proportional to the concentration of $\mathrm{NaOH}$ solution and steeping durations. The higher the $\mathrm{NaOH}$ concentration and longer steeping duration used, the higher the conversion efficiency when treated with enzyme. Alkali chemicals $(\mathrm{NaOH}, \mathrm{Ca}(\mathrm{OH}) 2$, and $\mathrm{KOH})$ were used in the pretreatment of rice straw, $\mathrm{NaOH}$ at $6 \%$ chemical loading was the best alkali concentration which achieved $85 \%$ increase of glucose yield by enzymatic hydrolysis (Zheng and Zhang 2009). This means that these pretreatment conditions aided in the opening of the rice straw's complex structure for the catalytic hydrolysis by the enzymes. 


\section{Study 2. Process of Bioethanol Production from Rice Straw}

The $\mathrm{NaOH}$ concentration and steeping duration which produced the highest amount of reducing sugars and conversion efficiency after enzymatic hydrolysis based on statistical analysis in Study 1 were chosen for Study 2. Thus, the pretreatment of rice straw using 1.5\% $\mathrm{NaOH}$ and steeped for 45 hours was selected for the alkali pretreatment in this study. Untreated rice straw was used as control.

Reducing Sugar Content of the Hydrolyzed Rice Straw Using Different Enzyme Combinations. Table 4 shows the reducing sugar of the enzyme hydrolyzed pretreated rice straw using different enzyme combinations. Results revealed that the highest reducing sugar observed was $0.7396 \mathrm{~g}$ using alkali pretreatment and three enzyme combinations. Lowest reducing sugar was $0.3944 \mathrm{~g}$ in untreated rice straw hydrolyzed using single enzyme.

Table 4. Reducing sugar (g) content of hydrolyzed pretreated and non-treated rice straw using different enzyme combinations.

\begin{tabular}{lcccc}
\hline \multirow{2}{*}{ Pre-treatment } & \multicolumn{3}{c}{ Enzymes } & \multirow{2}{*}{ Mean } \\
\cline { 2 - 4 } & Single & Two & Three & \\
\hline Control & $0.3944^{\mathrm{z}}$ & $0.4629^{\mathrm{y}}$ & $0.5442^{\mathrm{x}}$ & $0.4672^{\mathrm{b}}$ \\
Alkali & $0.4621^{\mathrm{y}}$ & $0.6572^{\mathrm{w}}$ & $0.7396^{\mathrm{v}}$ & $0.6197^{\mathrm{a}}$ \\
Mean & $0.4283^{\mathrm{k}}$ & $0.5600^{\mathrm{j}}$ & $0.6419^{\mathrm{i}}$ & \\
\hline
\end{tabular}

Means with the same letters in rows and in columns are not significantly different at $5 \%$ level of significance by DMRT

Analysis of variance showed highly significant differences in the reducing sugar of the alkali pretreated rice straw and control using different combinations of enzyme. In addition, there was also highly significant interaction effect noted between the pretreatment process and use of different enzyme combinations.

Comparison of means between reducing sugars produced on enzymatic hydrolysis of the rice straw in the treatment and control showed significant differences. Alkali pretreated rice straw had significantly higher reducing sugars produced at $0.6197 \mathrm{~g}$ compared to the control which has $0.4672 \mathrm{~g}$. An increase of $0.1525 \mathrm{~g}$ reducing sugars was observed in the rice straws pretreated with alkali.

Moreover, when the means of the reducing sugars produced by the different combinations of enzyme on the hydrolysis of rice straw were compared, highly significant differences were recorded at $1 \%$ level of confidence. The three enzyme combination produced the highest amount of reducing sugars at $0.6419 \mathrm{~g}$, while the lowest was in the use of single enzyme, cellulase complex, at $0.4283 \mathrm{~g}$. An increase of $0.1317 \mathrm{~g}$ was recorded when cellulase complex was combined with xylanase. Similarly, when combination of cellulase complex and xylanase was added with hemicellulase, an increase of $0.0819 \mathrm{~g}$ reducing sugar was observed.

Statistical analysis of the interaction of the pretreatment and use of enzyme combinations showed highly significant differences in the amount of reducing sugars produced. Highest reducing sugar was recorded in alkali pretreated rice straw hydrolyzed using three enzyme combination at 0.7396 g, followed by alkali pretreated rice straw hydrolyzed using two enzyme combination (0.6572 g), followed by untreated rice straw hydrolyzed using three enzyme combination $(0.5442 \mathrm{~g})$, followed by untreated rice straw hydrolyzed using two enzyme combination $(0.4629 \mathrm{~g})$, and alkali pretreated rice 
straw hydrolyzed using single enzyme $(0.4621 \mathrm{~g})$. The lowest was untreated rice straw hydrolyzed using single enzyme $(0.3944 \mathrm{~g})$. The reducing sugar of untreated rice straw hydrolyzed using two enzyme combination was comparable with the alkali pretreated rice straw hydrolyzed using single enzyme. However, the effect of three enzyme combination in untreated rice straw was lower than the alkali pretreated rice straw hydrolyzed using two enzyme combination.

Results imply that alkali pretreatment enhanced the release of fermentable sugars available in the rice straw through enzymatic hydrolysis. Alkali pretreatment can cause delignification of the amorphous and crystalline region of rice straw by breaking ester bonds cross-linking lignin and xylan, thus, increasing the porosity of biomass and making the cellulose more accessible to enzymes (Chen et al. 2007). This process also decreased the degree of polymerization (DP) and crystallinity of the cellulose component, thereby exposing it to the action of the hydrolytic enzyme like cellulase and other enzymes (Zheng et al. 2009). This explains the result of the use of three enzyme combination which helped in the release of more reducing sugar on enzymatic hydrolysis of the rice straw.

Conversion Efficiency of Different Enzyme Combinations on Untreated and Pretreated Rice Straw. Table 5 shows the conversion efficiency of different enzyme combinations on alkali pretreated and untreated rice straws. It can be seen from the table that the use of three enzyme combination had higher conversion efficiency than the use of two or single enzyme in both the control and alkali treatment. The mean conversion efficiency of the different enzyme combinations is $65.24 \%$ in the alkali treated while for the control, the mean conversion efficiency is $19.57 \%$. The effect of the pretreatment yielded 233 times conversion efficiency by the enzymes. However, highest conversion efficiency is recorded in the alkali pretreated rice straw hydrolyzed with three enzyme combination at $77.88 \%$ while the lowest was in the control hydrolyzed with single enzyme at $16.53 \%$.

Table 5. Conversion efficiency (\%) of different enzyme combinations on untreated and alkali treated rice straws.

\begin{tabular}{|c|c|c|c|c|}
\hline \multirow{2}{*}{ Pre-treatment } & \multicolumn{3}{|c|}{ Enzymes } & \multirow{2}{*}{ Mean } \\
\hline & Single & Two & Three & \\
\hline Control & $16.53^{z}$ & $19.39^{\mathrm{yz}}$ & $22.80^{y}$ & $19.57^{\mathrm{b}}$ \\
\hline Alkali & $48.65^{x}$ & $69.20^{\mathrm{w}}$ & $77.88^{\mathrm{v}}$ & $65.24^{\mathrm{a}}$ \\
\hline Mean & $32.59^{\mathrm{k}}$ & $44.30^{j}$ & $50.34^{\mathrm{i}}$ & \\
\hline
\end{tabular}

Means with the same letters in rows and in columns are not significantly different at $5 \%$ level of significance by DMRT

Analysis of variance revealed highly significant differences in the conversion efficiency between the experimental and control using different enzymes. There was also highly significant effect of the two factors, pretreatment process, and use of different enzymes on the conversion efficiency.

Comparison between means revealed that conversion efficiency of alkali pretreated rice straw at $65.24 \%$ was statistically higher compared to the untreated rice straw with $19.57 \%$ conversion efficiency. An increase of $45.67 \%$ conversion efficiency was recorded in rice straws which were alkali pretreated.

In terms of different enzyme combinations, comparison among treatment means of conversion efficiency after enzymatic hydrolysis of rice straw showed that the conversion efficiency of three enzyme combinations at $50.34 \%$ was significantly higher than two enzyme combination at $44.30 \%$ and single enzyme at $32.59 \%$. Similarly, conversion efficiency of two enzymes was higher than single enzyme. An increase of $11.71 \%$ conversion efficiency was observed when cellulose complex was added with xylanase. When the combination of cellulase complex and xylanase was added with hemicellulase, an increase of $6.04 \%$ conversion efficiency was recorded.

Vol. 2 No. 1 (March 2017) ISSN: 2507-9638 | DOI: 10.22137/ijst.2017.v2n1.02 
Statistical analysis revealed that there was highly significant interaction effect of the pretreatment and different enzyme combinations on the conversion efficiency after enzymatic hydrolysis of rice straws. Highest conversion efficiency was $77.88 \%$ recorded in alkali pretreated rice straw hydrolyzed using three enzyme combination, followed by alkali pretreated rice straw hydrolyzed using two enzyme combination at $69.20 \%$, followed by alkali pretreated rice straw hydrolyzed using single enzyme at $48.65 \%$, followed by untreated rice straw hydrolyzed using three enzyme combination at $22.80 \%$, and two enzyme combination at $19.39 \%$. The lowest was obtained in untreated rice straw hydrolyzed using two enzyme combination at $19.39 \%$ and single enzyme at $16.53 \%$. Conversion efficiency of untreated rice straw hydrolyzed using single enzyme was comparable with untreated rice straw hydrolyzed using two enzyme combination. Similarly, conversion efficiency of untreated rice straw hydrolyzed using two enzyme combination was comparable with untreated rice straw hydrolyzed using three enzyme combination. However, effect of three enzyme combination in untreated rice straw was lower than alkali pretreated rice straw hydrolyzed using single enzyme.

Results revealed that alkali pretreatment of rice straw enhanced the conversion efficiency of enzymatic hydrolysis. The enzymatic hydrolysis of native cellulose in biomass is usually less than $20 \%$ unless extremely excessive enzyme dose is used (Zheng et al. 2009). This study found it to be true, since the use of three enzyme combination had the highest conversion efficiency and the use of single enzyme had the lowest conversion efficiency.

Ethanol Yield. Percent ethanol yield is the ethanol yield calculated as percentage of the theoretical maximum ethanol yield. Table 6 presents percent ethanol yield on yeast fermentation of hydrolysates as influenced by pretreatment method and different enzyme combinations. Highest percent ethanol yield was recorded at $51.51 \%$ in the alkali pretreated rice straw hydrolyzed using single enzyme. The lowest was $41.18 \%$ in the untreated rice straw hydrolyzed using three enzyme combinations.

Table 6. Percent theoretical ethanol yield (\%) on yeast fermentation of hydrolysates as influenced by pretreatment and different enzyme combinations.

\begin{tabular}{|c|c|c|c|c|}
\hline \multirow{2}{*}{ Pre-treatment } & \multicolumn{3}{|c|}{ Enzymes } & \multirow{2}{*}{ Mean } \\
\hline & Single & Two & Three & \\
\hline Control & 45.94 & 43.33 & 41.18 & $43.49^{\mathrm{b}}$ \\
\hline Alkali & 51.51 & 47.88 & 46.33 & $48.57^{\mathrm{a}}$ \\
\hline Mean & 48.73 & 45.60 & 43.76 & \\
\hline
\end{tabular}

Means with the same letters in rows and in columns are not significantly different at $5 \%$ level of significance by DMRT

Analysis of variance showed that pretreatment had a significant effect in the percent ethanol yield while the use of different enzyme combinations and the interaction of the two factors showed no significant reaction.

Comparison among means on percent ethanol yield on yeast fermentation of hydrolysates showed that alkali pretreated rice straw had significantly higher ethanol yield at $48.57 \%$ than the untreated rice straw at $43.49 \%$.

Results revealed that ethanol yields of alkali pretreated rice straw hydrolyzed using single enzyme cellulase complex yielded the highest percent ethanol of $51.51 \%$. Yield of ethanol ranged from $0.0354 \mathrm{~g}$ to $0.0781 \mathrm{~g} / \mathrm{g}$ glucose. Ethanol yields in this study are at the lower end of the reported range for crop residues. Ethanol yield ranged from $52.00 \%$ to $65.82 \%$ of the theoretical maximum ethanol yield (Chen et al. 2007). This may be attributed to the fact that the yeast strain Saccharomyces cerevisiae was capable only of fermenting glucose release from holocelluloses of rice straw. The addition of xylanase and hemicellulase did not result in additional yield of ethanol.

Vol. 2 No. 1 (March 2017) ISSN: 2507-9638 | DOI: 10.22137/ijst.2017.v2n1.02 


\section{Acknowledgments}

The financial support of Engineering Research and Development for Technology (ERDT) is highly recognized in this paper.

\section{REFERENCES}

Chen, Ye, Ratna R. Sharma-Shivappa, Deepak Keshwani, and Chengci Chen. 2007. "Potential of Agricultural Residues and Hay for Bioethanol Production." Applied Biochemistry and Biotechnology 142: 276-290.

Corpuz, Perfecto G. 2010. "Philippines Biofuels Annual: Philippine Biofuels Situation and Outlook." Global Agricultural Information Network Report. Accessed January 23, 2011. https://gain.fas.usda.gov/Recent $\% 20$ GAIN $\% 20$ Publications/Biofuels $\% 20$ Annual Manila Phi lippines 7-9-2010.pdf

Kargbo, Foday Robert, Junjun Xing, and Yanling Zhang. 2007. "Pretreatment for Energy Use of Rice Straw: A Review." African Journal of Agricultural Research 4 (12). Accessed January 25, 2011. http://www.academicjournals.org/article/article1380817527_Kargbo\%20et\%20al.pdf

Sluiter, Amie D., Bonnie R. Hames, Deborah A. Hyman, Courtney E. Payne, Raymond O. Ruiz, Christopher J. Scarlata, Justin B. Sluiter, David W. Templeton, and Jeffrey L. Wolfe. 2005. "Determination of Total Solids in Biomass and Total Dissolved Solids in Liquid Process Samples." Laboratory Analytical Procedure (LAP). NREL/TP-510-42621. National Renewable Energy Laboratory, Golden, Colorado.

Yano, Shinichi, Shinya Yokoyama, and Kenji Imou. 2008. "Estimation of Ethanol Production from Rice Straw and Baggase in Asian Countries.” Biomass Asia Workshop. Accessed February 1, 2011.http://www.biomass-asiaworkshop.jp/biomassws/06workshop/presentation/20 Yano.pdf

Zheng, Yi, Zhongli Pan, and Ruihong Zhang. 2009. "Overview of Biomass Pretreatment for Cellulosic Ethanol Production.” International Journal of Agricultural and Biological Engineering 2(3): 51-68.

Zhong, Weizhang, Zhongzhi Zhang, Wei Qiao, Pengcheng Fu, and Man Liu. 2011. "Comparison of Chemical and Biological Pretreatment of Corn Straw for Biogas Production by Anaerobic Digestion." Renewable Energy 36 (6): 1875-1879 